\title{
Příležitosti k učení: odlišná/různá pojetí konceptu a jeho výzkumné využití1
}

\author{
Petr Knecht \\ Masarykova univerzita, Pedagogická fakulta, Institut výzkumu školního vzdělávání
}

Redakci zasláno 23. 10. 2013 / upravená verze obdržena 16. 4. 2014 /

$\mathrm{k}$ uveřejnění přijato 23. 4. 2014

\begin{abstract}
Abstrakt: Cílem přehledové studie je vymezit příležitosti k učení jako teoretický koncept, představit vybrané metody a techniky, které jsou ke zkoumání př́ležitostí nejčastěji využívány, a následně porovnat rozdíly v obsahovém vymezování příležitostí k učení v ČR a v USA, odkud tento koncept pochází. V první části studie je představen historický vývoj přístupů vymezování obsahu příležitostí k učení od 60. let 20. století do současnosti. Zpočátku byly př́ležitosti k učení nazírány jako teoretická kategorie adresující problém vztahu obsahu výuky a obsahových požadavků (standardizovaných) testů, příp. kurikulárních dokumentů. Později se obsahové vymezení konceptu rozšířilo směrem ke zkoumání školních i mimoškolních faktorů souvisejících s učebními výsledky žáků. $V$ druhé části příspěvku jsou popsány pokusy o operacionalizaci příležitostí k učení včetně př́ikladů výzkumných nástrojů používaných k jejich zkoumání. Studie na vybraných výzkumech ukazuje, že koncept příležitostí k učení v zahraničí zastřešuje především komplexnější výzkumy založené na analýze vztahu mezi vyučováním a učením s cílem poskytovat informace o makrorovině či mezorovině školského systému. To kontrastuje s pojetím př́ležitostí k učení převládajícím u nás, kde příležitosti $\mathrm{k}$ učení bývají především prezentovány jako teoretické východisko k realizaci mikroanalýz výuky na úrovni analýzy výukových situací.
\end{abstract}

Klíčová slova: příležitosti k učení, vzdělávací příležitosti, výzkum výuky, kurikulum

Příležitosti k učení jsou teoretickým konceptem často užívaným zejména při zkoumání procesů vyučování a učení napříč obory školního vzdělávání. To je patrně důvodem, proč se k němu v zahraničí i u nás hlásí nemalé množství výzkumníků. Cílem předkládané přehledové studie ${ }^{2}$ je teoreticky rozpraco-

1 Vznik studie byl podpořen z projektu GAČR GPP407/12/P059 Př́ležitosti k rozvíjení kompetence $k$ řešení problémů $v$ učebnicích a ve výuce.

2 Jedná se o narativní přehledovou studii ukotvenou v diskursu kurikulárních studií, pro kterou je charakteristické teoretizování, vysvětlování, zdůvodňování a konstrukce př́iběhů (např. kurikulárních reforem) a jejich kritická reflexe. Narativní přehledová studie se odlišuje od přehledových studí typu systematic review, pro které je charakteristický důraz na jednoznačně definovaný výzkumný postup (k jednotlivým typům přehledových studií viz např. Mareš, 2013).

DOI: $10.5817 /$ PedOr2014-2-163 
vat př́ležitosti k učení a operacionalizovat je pro potřeby zkoumání kvality výuky (srov. např. Helmke, 2007, s. 42). Textem se snažíme volně navázat na nedávno publikované studie týkající se zkoumání kvality výuky publikované v českých pedagogických časopisech (srov. Janík, 2012; Slavík \& Janík, 2012; Janík, Lokajíčková, \& Janko, 2012 aj.). Nejprve přiblížíme specifický historický vývoj přístupů k vymezování obsahu příležitostí $\mathrm{k}$ učení a následně představíme vybrané výzkumné nástroje, které jsou k měření příležitostí nejčastěji využívány. Naše úsilí je motivováno snahou lépe a hlouběji porozumět procesům vyučování a učení odehrávajícím se ve školních třídách a potřebou tyto procesy vysvětlit a interpretovat. K výběru zdrojových textů jsme přistoupili nejprve systematicky s využitím běžně dostupných bibliografických databází (Web of Knowledge, Scopus, EBSCO, Proquest, Google Scholar) a následně jsme pomocí metody sněhové koule doplnili další relevantní texty (časopisecké články, monografie a kapitoly v monografiích), které př́ležitosti k učení teoreticky rozpracovávají, př́ípadně operacionalizují. Popsaná kritéria výběru zdrojových textů zužují záběr prezentovaných zjištění zejména na oblast anglicky psané odborné literatury, nebot' anglicky psaná literatura v současnosti dominuje odbornému diskursu.

\section{Příležitosti k učení: etablovaný teoretický konstrukt nebo floskule?}

Příležitosti k učení (angl. opportunities to learn) ${ }^{3}$ je možné definovat jako způsob nastavení sociálních, politických a pedagogických podmínek, které umožňují žákům získávat znalosti, rozvíjet dovednosti a utvářet postoje k obsahu různých vyučovacích předmětů (srov. Valverde et al., 2002, s. 6-9). U nás je toto široké výzkumné pole redukováno zejména na výzkumy, jež se zaměřují na oblast vstupů, tj. vzdělávací nabídky a s ní souvisejících procesů. Tyto výzkumy vycházejí z postulátu, že školní výuka by měla nabízet co nejvíce př́ležitostí $\mathrm{k}$ tomu, aby žáci byli podněcováni k učení. Operují v mikrorovině školského systému, tj. ve školních třídách, a jsou založeny především na analyzování výukových situací, které mají povahu určité výzvy podněcující žáky k tomu, aby se zabývali učivem. Takto chápaný koncept př́ležitostí $\mathrm{k}$ učení zastřešuje např́klad videostudie realizované Institutem výzkumu

3 V anglicky psané odborné literatuře je možné setkat se mimo termínu opportunities to learn také s termínem learning opportunities (viz např. Crabbe, 2007). V této práci vzhledem k problematickému překladu a obsahovému překryvu obou termínů používáme sjednocující termín př́ležitosti $k$ učení. 
školního vzdělávání PdF MU (souhrnně k jednotlivým analýzám viz Najvar et al., 2011) i další výzkumy (Chvál, Kasíková, \& Valenta, 2012; Chvál \& Kasíková, 2011). Operacionalizace př́ležitostí $\mathrm{k}$ učení v uvedených výzkumech staví na tradičních předmětech zájmu výzkumu výuky, jako jsou např. organizační formy a fáze výuky (Najvar, Najvarová, \& Janík, 2009), podpora žákům v průběhu učení, charakteristika učebních úloh apod. (Chvál et al., 2012), nebo je zaměřena na specifické oborově didaktické aspekty výuky: didaktické rídicí styly (Janíková, 2011), rozvíjení nadoborových kompetencí (Knecht et al., 2010), oborově specifických kompetencí (Lokajíčková, 2013; Zerzová, 2012) nebo dovedností (Šebestová, 2011).

Pro obecné i oborově specifické aspekty výuky jsou v těchto výzkumech poměrně pracně vytvářeny a ověřovány speciální kategoriální systémy a škály, které následně slouží k deskripci, případně k evaluaci výukových situací. Výsledky těchto výzkumů bývají zř́́dkakdy zpětně vztahovány k teoretickým východiskům - zejména ke konceptu příležitostí k učení. To evokuje otázku, zda je možné příležitosti k učení považovat za potřebný teoretický konstrukt, nebo reprezentují jeden z mnoha „kontejnerových termínů", kterým je možné zastřešit prakticky jakýkoli výzkum týkající se obsahové dimenze výuky. Školu jako instituci je možné vnímat jako kulturně determinovanou př́ležitost $\mathrm{k}$ učení sui generis, tudíž se předpokládá, že školní výuka více či méně implicitně nějaké př́ležitosti $\mathrm{k}$ učení skutečně nabízí. Zájem výzkumníků v oblasti vzdělávání se $\mathrm{v}$ současnosti týká především povahy těchto př́ležitostí a souvisejících interpretací.

\section{Příležitosti k učení: teoretické a historické explanace}

V této podkapitole se snažíme popsat historický vývoj obsahového vymezování př́ležitostí $\mathrm{k}$ učení jako teoretické kategorie a jejich empirickovýzkumné operacionalizace, se zvláštním zřetelem k vývoji v USA, odkud tento koncept pochází.

4 Toto vymezení př́ležitostí k učení bylo inspirováno ve vybraných zahraničních výzkumech (Seidel et al., 2006 aj.), které kladou důraz především na zkou mání učebních úloh, které jsou žákům předkládány $\mathrm{k}$ řešení. 


\subsection{Příležitosti k učení jako kategorie vyjadřující koherenci obsahu výuky a obsahu (standardizovaných) testů}

Na pozadí šoku ze Sputnika bylo možné v 60. letech 20. století v západních zemích pozorovat zvýšenou kurikulární aktivitu akcentovanou zejména reformami kurikula matematického a přírodovědného vzdělávání. Termín př́ležitosti $k$ učení byl zřejmě poprvé použit $\mathrm{v}$ rámci mezinárodního srovnání vzdělávacích výsledků v matematice FIMS (First International Mathematics Study, 1963-1967) ${ }^{5}$. Zde se mimo jiné zjišt’ovalo, zda žáci měli k dispozici dostatek výukového času na to, aby úspěšně zvládli všechny testové úlohy. Carroll (1963) navrhl konceptuální model faktorů, které ovlivňují školní úspěšnost žáků, zahrnující nadání, schopnost rozumět výkladu, kvalitu výuky a př́ležitosti $\mathrm{k}$ učení ve výuce (chápané jednak jako výukový čas vymezený určitému učivu a jednak jako čas, který žáci stráví aktivním učením). Model vycházel z předpokladu, že čas, který žák potřebuje $\mathrm{k}$ tomu, aby se něco naučil, je ovlivněn kvalitou výuky a př́ležitostmi k učení (podrobněji viz Janík et al., 2013, s. 49-50). Klíčovou otázkou bylo zjistit, jakými znalostmi a dovednostmi disponují žáci poté, co absolvovali školní výuku. Výzkum FIMS totiž ukázal, že množství času věnovaného učení souvisí s množstvím osvojeného učiva a v pozadí rozdílných výsledků žáků patrně mohou být také odlišnosti v kurikulu. Carollův model vycházel vstříc potřebě citlivější interpretace výsledků standardizovaného testování žáků, která byla nezbytným předpokladem pro zpětné (pře)nastavení vzdělávací politiky. Př́ležitosti k učení se tak poměrně rychle etablovaly jako teoretický koncept a staly se zastřešujícím východiskem výzkumů zjištujuících, zda žáci měli př́ležitost naučit se určité obsahy nebo naučit se řešit určitý typ problému, který byl obsažen v nějakém testu školní výkonnosti.

\subsection{Příležitosti k učení jako kategorie zahrnující obsahy, procesy a aktéry výuky}

Až do 80. let 20. stol. byly př́ležitosti k učení teoretickým konceptem, později se výsledky měření př́ležitostí $\mathrm{k}$ učení staly východiskem pro tvorbu indikátorů kvality výuky. Výsledky výzkumu SIMS (Second International Mathematics Study, 1983-1986) upozornily na souvislost mezi obsahem, se kterým se žáci ve výuce setkávají, a jejich školní výkonností. Mnozí výzkumníci se následně začali intenzivněji zajímat o to, co se děje mezi vstupem a výstu-

Zatímco prvního mezinárodního šetření FIMS se zúčastnilo 12 zemí, v roce 2011 se navazujícího šetření TIMSS zúčastnilo 69 zemí (resp. samostatných vzdělávacích systémů). 
pem vzdělávání jako reakce na desítky textů kritizujících tehdejší školství a zprávy, které upozorňovaly na zhoršující se výsledky amerických žákư a neustálé snižování požadavků kladených na žáky (srov. např. zpráva $\mathrm{Na}$ tion at risk; viz Gardner, Larsen, \& Baker, 1983). Vyvstala potřeba takových dat, která by zprostředkovala srozumitelný obraz toho, jak v jednotlivých školách a školních třídách probíhá výuka (Dougherty, 1996, s. 41). Chápání př́ležitostí k učení se posunulo dále, než bylo např́íklad v 60. letech 20 . stol., kdy zahrnovalo pouze překryv vyučovaného a testovaného učiva. Př́ležitosti k učení byly definovány složitějšími teoretickými modely, které zahrnovaly nejen učivo, se kterým se žáci setkali ve výuce, ale také faktory zachycující, jak a kým jim bylo učivo zprostředkováno (Shavelson, McDonnell, \& Oakes, 1989). Obsahový záběr př́ležitostí k učení se postupně rozrůstal o další faktory, např. čas věnovaný určitým tematickým celkủm učiva, materiální a personální zdroje a způsoby hodnocení žáků. $V$ návaznosti na sociologické výzkumy vzdělávání ${ }^{6}$ se ukazovalo, že pro posuzování př́ležitostí k učení je nezbytné srovnávat podmínky vzdělávání v různých lokalitách a u různých typů žáků. Tyto informace byly cenné také pro tvưrce vzdělávací politiky, nebot' na jejich základě mohly školy přebírat zodpovědnost za vzdělávací výsledky svých žáků. Předpokládalo se, že tlak na výsledky si vynutí změnu systému směrem k poskytování materiálních a lidských zdrojů zajišt’ujících rovné příležitosti ve smyslu dosahování předepsaných cílů vzdělávání, nebot' je v zájmu škol postarat se o to, aby jejich žáci měli ty nejlepší výsledky. S tímto opatřením často souvisely administrativní sankce a restrikce pro školy, které neměly očekávané výsledky. To uvrhlo školy navštěvované slabšími žáky téměř do izolace, mj. proto, že svou pověstí odrazovaly také učitele (podrobněji viz McDonnell, 1995, s. 324). Na konci 80. let se zvýšil počet žáků, kteří nedokázali plnit požadavky stanovené náročnějším kurikulem. To přineslo obrovský tlak na žáky i na školy. Začaly sílit hlasy, že reformy kurikula nejsou doprovázeny reformami v oblasti sociálního uspořádání škol tak, aby byly zajištěny rovné vzdělávací př́ležitosti pro všechny žáky $\mathrm{k}$ dosažení náročných standardů (podrobněji viz McPartland \& Schneider, 1996, s. 72).

Tyto zprávy mobilizovaly veřejnou podporu pro opatření, která měla dalšímu zhoršování zabránit. Začalo sílit hnutí prosazující celostátní standardizované testování vzdělávacích výsledkủ. Za nástroj systémové změny bylo považováno zavedení národních vzdělávacích standardů na počátku 90. let

6 Výzkumy zjištujuící dostupnost vzdělávacích příležitostí u různých typů žáků byly realizovány již od 60. let 20. stol. (viz např. Coleman, 1966). 
20. stol. (podrobněji viz Gamoran, 2007). Cílem bylo zmírnit nepříznivé dopady celostátního testování na žáky pocházející z minorit, př́íp. na žáky, kteří navštěvovali horší školy, a poskytnout všem žákům příležitost setkat se ve výuce s náročným obsahem. Někteří výzkumníci poukazovali, že standardy mohou být chápany jako idealistická vize vzdělávání vycházející z mylné premisy, že jeden dokument zajistí, že všichni žáci budou zvládat náročné obsahy (Dougherty, 1996, s. 43). Dále bylo kritizováno, že není korektní, aby žáci byli testováni na znalost něčeho, $\mathrm{k}$ čemuž nedostali př́ležitost se naučit. Na druhou stranu zastánci standardizace upozorňovali, že bez standardů se není možné dozvědět, zda existují špatné školy, nebo jen špatní žáci.

\subsection{Příležitosti k učení jako kategorie zahrnující vícečetné faktory ovlivňující školní úspěšnost žáků}

Koncept př́ležitostí k učení postupem času proměnil nazírání výzkumníků, učitelů i tvůrců vzdělávací politiky na determinanty žákova učení. V 90. letech 20. stol. se obsahové vymezení príležitostí $\mathrm{k}$ učení ještě více rozšírilo. Začalo se zkoumat, jak se liší příležitosti k učení, které se dostávají různým typům žáků (dle pohlaví, sociálního a etnického původu, místa bydliště aj.), a postupně byly přidávány další školní i mimoškolní faktory týkající se vnější diferenciace žáků a distribuce rovných vzdělávacích př́ležitostí (srov. např. Darling-Hammond, 1992; Oakes, 1992). Příležitosti k učení se následně staly také nosným konceptem kurikulární politiky, která si kladla za cíl zajištění rovných vzdělávacích příležitostí. $\mathrm{V}$ dokumentu Raising standards for American education (1992) př́ležitosti k učení rámovaly požadavek, aby školní kurikula zahrnovala obsah definovaný vzdělávacími standardy, aby školy zaměstnávaly kvalifikované učitele, aby měly k dispozici vhodné výukové materiály a měly podmínky pro zajištění př́ležitosti $\mathrm{k}$ dosahování očekávaného standardu u všech žáků.

I nadále se ukazovalo, že výsledky žáků přímo nesouvisí s obsahem školní výuky. Jak naznačily některé teoretické modely, distribuce zdrojů určených na vzdělávání i přístup ke vzdělávání byly rozděleny nerovnoměrně. Nejméně kvalifikovaní učitelé vyučovali sociálně slabé žáky a žáky pocházející z minorit. Vysoký vliv na úspěšnost žáků mělo také rodinné prostředí, příslušnost k určité rase, pohlaví, etniku, sociální skupině nebo geografické lokalitě (srov. Schneider \& Coleman, 1993). Př́ležitosti k učení v tomto období představovaly teoretický koncept, kterým se zjištovalo, zda školy poskytují žákům rovné př́ležitosti $\mathrm{k}$ tomu, aby se naučili učivo obsažené ve standardech. 
$\mathrm{V}$ roce 1997 byly zavedeny standardy př́ležitostí $\mathrm{k}$ učení zaměřené především na zjištování a měření faktorů, které přímo ovlivňují učení žákủ (srov. Goals 2000: Educate America act). Ve vymezování př́ležitostí k učení byl kladen důraz zejména na výukové procesy, související školní a mimoškolní podmínky a lidské i materiální zdroje (podrobněji viz Porter, 1995). Smyslem standardů bylo zajistit, aby všichni žáci měli př́ležitost setkat se ve výuce se stejným (stejně náročným) učivem umožňujícím hluboké konceptuální porozumění, aplikaci znalostí při zdůvodňování a řešení problémů a efektivní odbornou komunikaci (Wiley \& Yoon, 1995, s. 356). Školy měly dále naplňovat minimální standard v následujících oblastech: kvalifikace učitelů a jejich další vzdělávání, dostupnost školních pomůcek, financování zabezpečení škol, délka školní výuky atd. Obsahové vymezení př́ležitostí k učení bylo ovlivněno citlivou otázkou spravedlivosti ve vzdělávání, zejména s ohledem na žáky ohrožené tím, že se nemusí plně rozvinout jejich akademický potenciál. Hermanová a Kleinová (1997, s. 1) v tomto období definovaly př́ležitosti k učení jako soubor proměnných, které ve školní výuce podporují procesy učení a učební pokroky žáků s ohledem na stanovené cíle vzdělávání. Vzápětí po implementaci standardů př́ležitostí k učení se ukázalo, že některé školy nejsou s to dosáhnout ambiciózních vzdělávacích cílů kvůli různorodosti žáků, kteří je navštěvují. Slabším žákům, zejména příslušníkům minorit, např́ílad nebyly nabízeny náročnější kurzy, a pokud ano, tak ne v potřebné míře ${ }^{7}$. Tito žáci tak měli méně př́ležitostí setkat se $s$ náročnějším obsahem - jejich výuka spočívala spíše v drilu a procvičování než v rozvíjení náročnějších způsobů myšlení a uvažování, které jsou typické pro výuku nadaných žáků (srov. Gross, 1993, s. 270). Účast žáků v náročnějších výukových kurzech je nicméně předpokladem k navazující pokročilejší práci ve vyšších ročnících. Učitelé na uvedené skutečnosti reagovali tím, že se začali orientovat především na plnění obsahových požadavků, aby zaručili dosažení standardu př́íslušného oboru. Náročnější požadavky na učení žáků nicméně přinesly zhoršující se problémy s disciplínou žákủ. Ústředním problémem se stalo dilema, jak vybalancovat expertní pojetí výuky a pozitivní výukové klima. Další vývoj ukázal, že standardy příležitostí k učení nepřihlížely k některým dalším mimoškolním faktorům (rasová a třídní příslušnost, rodinné zázemí, vzdělávací aspirace, motivace žáků a povědomí o fungování školního vzdě-

7 Výzkumy ukazují, že vnitřní diferenciace žáků nemá vliv na jejich školní výkonnost. Integrace naopak může v některých prŕṕpadech výkony žáků zvýšit (srov. Welner \& Oakes, 2008; podrobněji viz také Dvořák, 2010 a zejména Veselý a Matějů, 2010). Existují ale také výzkumy, které tento postulát popírají (srov. Mudrák \& Zábrodská, 2013, s. 204). 
lávání). Rozdíly v odpovědích žáků na určité testové úlohy naznačovaly, že klíčovou roli ve výsledcích vzdělávání mohou hrát právě mimoškolní faktory.

Razantní změny v kurikulární politice USA na přelomu tisíciletí přinesl především dokument No child left behind act (2002; srov. také Loveless, 2006), který předepisoval, že jednotlivé státy, okresy, školy a učitelé musí dosahovat ambiciózně stanovených cílů vzdělávání u všech žáků, tedy i u těch, kteří plně neovládají anglický jazyk. Oproti předchozímu období, kdy byla spravedlivost ve vzdělávání chápána jako distribuce rovných vzdělávacích př́ležitostí ve smyslu inkluze (rovnost v př́stupu), byla nyní rovnost př́ležitostí chápána jako předpoklad, že všichni žáci budou ve školní výuce vystaveni kognitivně náročnému jazyku zasazenému do akademických kontextů (rovnost podmínek; podrobněji viz Martínez et al., 2010). ${ }^{8}$ Výuka se stala obsahově náročnější, zvýšila se výrazně vazba mezi testovaným a vyučovaným obsahem (fenomén teaching to the tests). $\mathrm{V}$ současnosti se zájem výzkumníků soustředí na opatření, která by měla napomáhat znevýhodněným žákům s ohledem na rovnost výstupu vzdělávání. Jako důležitá dimenze př́ležitostí k učení je aktuálně posuzován individuální pokrok žáka v určitém čase (tzv. progress score). Diskurs týkající se přiležitostí k učení ve výuce začíná v současnosti postupně prolínat s diskursem zaměřeným na zjištování indikátorů kvality výuky. Patrně také z tohoto důvodu již zájem výzkumníků o př́ležitosti $\mathrm{k}$ učení postupně klesá. Přesto je možné prohlásit, že mnohé $\mathrm{z}$ dimenzí př́ležitostí $\mathrm{k}$ učení se i nadále těší zájmu výzkumníků, ačkoliv jsou zastřešeny teoretickým konceptem kvality výuky (podrobněji viz Janík, Lokajíčková, \& Janko, 2012).

Pokud bychom měli shrnout výše uvedené, je možné konstatovat, že pokusy o definování př́ležitostí $\mathrm{k}$ učení prošly několika fázemi. Zpočátku byly př́iležitosti k učení nazírány jako teoretická kategorie vypovídající o obsahové skladbě výuky a/nebo o (ne)souladu obsahu výuky a obsahových požadavků (standardizovaných) testů, př́íp. kurikulárních dokumentů. Později se záběr př́ležitostí k učení rozšíril směrem ke zkoumání školních i mimoškolních faktorů determinujících školní úspěšnost žáků. Obsahové vymezování příležitostí $\mathrm{k}$ učení tak do značné míry ovlivnil metodologický př́ístup k jejich zkoumání, nebot' postupem času výzkumníci vytvářeli složitější výzkumy a složitější operacionalizace. Jednotlivé vývojové fáze obsahového vymezo-

8 Koncepty související s rovností př́ležitostí ve vzdělávání (rovnost v přístupu ke vzdělávání, rovnost podmínek vzdělávání, rovnost výsledků aj.) podrobněji vymezuje Greger (2006, 2010). 
vání př́ležitostí k učení jako teoretické kategorie není možné striktně odlišovat, spíše se jedná o ideálně typická vymezení charakteristická pro příslušná časová období. Jednotlivé fáze obsahového vymezování př́ležitostí k učení chápeme jako dialektický proces, $\mathrm{v}$ rámci kterého mohou různá pojetí př́ležitostí k učení v různých výzkumech vedle sebe souběžně existovat. Obsahové vymezování teoretických kategorií do jisté míry závisí na motivaci, cílech, potřebách a přesvědčeních jednotlivých autorů. Pokud bychom příležitosti k učení oprostili od všech souvisejících kontextových aj. proměnných, lze je nazírat jako koncept, který do komplexnějších výzkumů širších témat výzkumu vzdělávání (vnější diferenciace, spravedlivosti ve vzdělávání, efektivity výuky) vstupuje jako jedna z kurikulárních proměnných. Zároveň ale mohou př́ležitosti k učení teoreticky zastřešovat také jednodušší výzkumy, jejichž cílem je pouze sledovat př́ležitosti $\mathrm{k}$ učení a následně je popisovat. Poté, co jsme představili příležitosti k učení jako teoretický koncept, se v následující podkapitole věnujeme vybraným možnostem jejich empiricko-výzkumného uchopování.

\section{Příležitosti k učení z pohledu pedagogického výzkumu}

Na základěpředešlého historického ohlédnutílze odvodit,žeoperacionalizace prríležitostí $\mathrm{k}$ učení a související výzkumné nástroje se vyvíjely v závislosti na tom, jak byly př́ležitosti k učení definovány. Ačkoliv se toto konstatování může jevit jako triviální, poměrně zdařile zdůvodňuje pestrou paletu výzkumných metod a technik, které bývají $\mathrm{k}$ měření př́ležitostí $\mathrm{k}$ učení využívány.

\subsection{Výzkum príležitostí $k$ učení jako příležitostí se něčemu (na)učit}

Jak uvádíme v předchozí kapitole, v 60. letech 20. stol. sloužil koncept př́ležitostí k učení ke zjištování, zda školy poskytují žákům př́ležitost naučit se učivo potřebné k úspěšnému zvládnutí standardizovaných testů školní výkonnosti. Hlavním nástrojem pro zkoumání příležitostí k učení byly dotazníky, kterými se na základě odpovědí učitelů zjištovalo, zda a s jakou časovou dotací bylo ve výuce probráno učivo, které je nezbytné pro správné zodpovězení jednotlivých položek v žákovských testech (viz např. Caroll, 1963; Cooley \& Leinhardt, 1980 aj.) $)^{9}$. Obdobně koncipované výzkumy srovnávaly výpovědi učitelů a žáků týkající se probraného učiva (viz např. Herman \& Klein, 1997)

9 Podrobný přehled výzkumů viz Wang (1998, s. 138). 
nebo zjištovaly názory učitelů, zda a v jaké míře budou jejich žáci úspěšní v jednotlivých testových otázkách. Př́ležitosti k učení koncepuálně zastřešovaly také výzkumy implementační fidelity (termín vymezuje Stará, 2011), ve kterých výpovědi učitelů sloužily jako zdroj informací o úspěšnosti kurikulárních reforem. Wiley a Yoonová (1995) např́klad na vzorku 1750 kalifornských učitelů zjištovali, zda žáci měli ve výuce matematiky dostatek príležitostí setkat se s inovovanými vzdělávacími obsahy a výukovými postupy a jaké faktory (obeznámenost s kurikulárními dokumenty, další vzdělávání aj.) tyto př́ležitosti ovlivňují. Metodologický přístup založený převážně na sběru informací od učitelů byl často kritizován, nebot' takto získaná výzkumná data mohla být zatížena subjektivními interpretacemi respondentů (Schmidt \& McKnight, 1995, s. 344).

Zkoumání příležitostí k učení směřovalo k získávání podrobnějších informací o tom, co se skutečně děje $s$ učivem ve školních třídách. To vyžadovalo operacionalizaci př́ležitostí $\mathrm{k}$ učení pro potřeby výzkumu reálné výuky jednotlivých vyučovacích předmětů. Objevily se především otázky týkající se obsahové skladby výuky a souvisejících procesů vyučování a učení. Přestalo se zjištovat pouze to, co žáci vědí, př́padně s jakými obsahy se setkali ve výuce. Tato data byla oproštěna od jakýchkoli kontextuálních proměnných, což pochopitelně znemožňovalo správnou a hlubší interpretaci výzkumných zjištění. Výzkumy př́ležitostí $\mathrm{k}$ učení se následně začaly více zaměřovat na rozdíly ve znalostech žáků a na to, jak rozdíly ve znalostech žáků souvisí se způsobem zprostředkování vzdělávacích obsahů ve školní výuce. V rámci mezinárodního výzkumu SIMS (Second International Mathematics Study, 1983-1986) byly sledovány kulturní a výukové postupy a jejich mezinárodní odlišnosti $\mathrm{s}$ cílem vysvětlit rozdíly ve výkonech žáků. Př́ležitosti $\mathrm{k}$ učení ve výzkumu SIMS představovaly jedinou proměnnou související s děním ve třídě. Př́ležitosti k učení byly operacionalizovány pomocí dvou kategorií: pokrytí obsahu (angl. content coverage) a expozice (vystavení) obsahu (angl. content exposure). Př́ležitosti k učení v širším pojetí (angl. educational opportunity) ${ }^{10}$ se následně staly také centrálním konceptem mezinárodního srovnávacího výzkumu TIMSS (realizován v letech 1995, 1999, 2003, 2007 a 2011). V pozadí výzkumu stála snaha o kontextualizaci výsledků vzdělávání, která je zachycena v komplexním modelu (Valverde et al., 2002, s. 6), který se soustředí na následující aspekty příležitostí k učení: požadavky předepsané kurikulár-

${ }_{10}$ Termín educational opportunity je možné v pojetí TIMSS překládat také jako vzdělávací př́ležitosti. 
ními dokumenty, charakteristiky učitele, charakteristiky výuky (organizace výuky, používání pomůcek, struktura výuky, výukový materiál, management třídy, evaluace, zapojení žáků do výukových aktivit, domácí úkoly, organizační formy aj.), znalosti a další charakteristiky žáků (podrobněji viz Schmidt \& McKnight, 1995, s. 349).

Výzkum TIMSS dále prohloubil zájem výzkumníků i tvůrců vzdělávací politiky o dění ve školních třídách. Stevens na základě syntézy dřívějších výzkumů o vztazích mezi komponentami a/nebo charakteristikami výuky a učebními výsledky žáků ${ }^{11}$ navrhl čtyřdimenzionální rámec př́ležitostí $\mathrm{k}$ učení (srov. Stevens, 1993, s. 233-234):

- Pokrytí obsahu (angl. content coverage) - jedná se o proměnnou udávající, zda se žáci ve výuce setkali s určitým učivem, např́íklad předepsaným kurikulárními dokumenty. Spadají sem také výzkumy vnitřní a vnější koherence kurikulárních dokumentů (k termínu viz Dvořák, 2011).

- Expozice (vystavení) obsahu (angl. content exposure) - proměnná udává celkový čas věnovaný výuce (př́íp. výuce určitého učiva) a hloubku zprostředkování tohoto učiva.

- Důležitost obsahu (angl. content emphasis) - proměnná poskytuje informaci o tom, jak se z hlediska cílů a obsahů liší výuka slabších a nadaných žáků, které obsahy a tematické celky učiva jsou u těchto skupin žáků ve výuce považovány za hlavní nebo vedlejší a jaké myšlenkové procesy jsou u jednotlivých typů žáků v př́ípadě těchto obsahů rozvíjeny (čisté memorování nebo napřs samostatné řešení problémů).

- Kvalita vyučovacích postupů (angl. quality of instructional delivery) na základě této proměnné je možné zjistit, jak výukové postupy a strategie uplatňované učiteli ovlivňují školní úspěšnost žáků. Vychází se z předpokladu, že různí učitelé vytvářejí rozdílná učební prostředí v závislosti na svých dosavadních zkušenostech a různé úrovni didaktických znalostí obsahu. Zjištuje se mimo jiné, zda učitelé využívají písemné př́ípravy na výuku, pracují s chybou, vyučují koherentně, logicky propojují a sekvencují výukové aktivity, využívají různé pomůcky, učebnice apod.

11 Východisko představovaly dnes již klasické výzkumy vycházející z paradigmatu procesprodukt (např. Leinhardt \& Seewald, 1981; Brophy \& Good, 1986; McDonnell et al., 1990 apod.). 
Z vymezení Stevense vycházeli také další výzkumníci, kteří v USA zkoumali souvislosti mezi prŕležitostmi k učení a dalšími proměnnými, např́íklad dostupností materiálních a personálních zdrojů, podmínkami vzdělávání, obsahem kurikulárních dokumentů apod. (Brewer \& Stacz, 1996; Stevens, Wiltz, \& Bailey, 1998; Wang, 1998). Zmiňované výzkumy shodně ukazují, že jednotlivé dimenze př́ležitostí k učení představují indikátory, které mohou ovlivňovat školní úspěšnost žáků.

Neobvyklou metodu měření př́ležitostí k učení ve výuce matematiky použili Cueto, Ramirezová a Leon (2006). Na základě obsahové analýzy 44 pracovních sešitů a 83 školních sešitů peruánských žáků (jednalo se vždy o sešity dvou nejlepších žáků ze tř́dy nominovaných učitelem) se snažili získat podrobnější informace o pokrytí obsahu a důležitosti obsahu (dvě z dimenzí př́ležitostí $\mathrm{k}$ učení vymezených Stevensem). V sešitech dále analyzovali správnost řešení obsažených učebních úloh a zpětnou vazbu ze strany učitelů. Ukázalo se, že učitelé ve výuce většinou upřednostňují určitá témata, zatímco jiná vynechávají. Výrazně méně témat při nedostatečné hloubce jejich zprostředkování bylo možné pozorovat zejména na školách navštěvovaných žáky pocházejícími ze sociálně znevýhodněného prostředí a ve školách s více spojenými ročníky.

\subsection{Výzkum př́ležitostí $k$ učení za účelem zajištění rovných přiležitostí a spravedlivosti ve vzděláváníi ${ }^{12}$}

V 90. letech 20. století se staly př́ležitosti k učení centrálním teoretickým konceptem studií zkoumajících vztah mezi školní úspěšností žáků a jejími hlavními determinantami (rasová/etnická příslušnost, sociální původ, organizační struktura škol, zdroje podpory apod.). Toto chápání konceptu př́ležitostí k učení vyžadovalo také rozšíření instrumentária souvisejících výzkumných metod a technik. To umožňovalo jednotlivým faktorům ovlivňujícím školní úspěšnost hlouběji porozumět a následně vyvíjet mechanismy podpory znevýhodněných žáků. Důsledkem rozšíření množství kontextuálních proměnných zjištovaných $\mathrm{v}$ rámci výzkumů př́ležitostí $\mathrm{k}$ učení bylo postupné oslabení zájmu o podrobné zkoumání povahy výukových procesů ve školních třídách. Pozornost výzkumníků se postupně přesouvala do makroroviny

12 Jeden $\mathrm{z}$ anonymních recenzentů příspěvku upozornil, že příležitosti $\mathrm{k}$ učení není na místě nadřazovat konceptům rovnosti př́ležitostí, spravedlivosti ve vzdělávání nebo diferenciace žáků, nebot' se jedná pouze o menšinový přístup některých autorů široce nesdílený odbornou komunitou. 
a mezoroviny vzdělávacího systému. Cílem bylo především systematické mapování vnitřních a vnějších podmínek vzdělávání za účelem zajištění rovných př́ležitostí a spravedlivosti ve vzdělávání (širší politické souvislosti problematiky popisují Guitonová a Oakesová, 1995).

Mnohé z výzkumů př́ležitostí $\mathrm{k}$ učení se zaměřovaly na problematiku vnitřní a vnější diferenciace žáků. Tyto výzkumy upozorňovaly, že obsahová náplň výuky bývá v kurzech určených pro různě nadané žáky odlišná, což může následně negativně ovlivňovat školní úspěšnost žáků. Grossová (1993) v USA na vzorku 603 žákủ zjistila, že učitelé ve třídách, ve kterých převládají slabší žáci, kladou důraz na dril a procvičování a nevěnují se praktické aplikaci znalostí a nepodporují rozvíjení náročnější myšlenkových operací. Tyto výukové postupy lze naopak častěji pozorovat ve třídách, ve kterých převládají žáci schopnější. Výzkum zároveň poukázal na problém, že žáci ve výkonově slabších třídách se setkávají $\mathrm{s}$ menším množstvím učiva a zároveň v těchto třídách působí méně zkušení učitelé. Zkoumání příležitostí k učení tak poskytovalo informace využitelné k zavádění kompenzačních mechanismů zajišțujících školní úspěšnost znevýhodněných žáků (tj. žáků z rodin s nižšími př́ijmy, příslušníků minorit aj.). K obdobným zjištěním dospěly také navazující výzkumy (Stevenson, Schiller, \& Schneider, 1994; Muthén et al., 1995; Gamoran et al., 1997 aj.).

Další výzkumy zaštitované konceptem příležitostí $\mathrm{k}$ učení usilovaly o identifikaci faktorů ovlivňujících školní úspěšnost zejména jazykově znevýhodněných žáků. Očekávalo se, že by se všichni žáci bez ohledu na své jazykové schopnosti měli ve školní výuce setkat s odborným jazykem zasazeným do akademických kontextů (rovnost podmínek). Tento požadavek byl definován jako jeden $\mathrm{z}$ indikátorů spravedlivosti $\mathrm{v}$ dokumentu No child left behind act (2002). Pozornost výzkumníků zabývajících se zkoumáním příležitostí $\mathrm{k}$ učení $\mathrm{v}$ USA se patrně $\mathrm{z}$ tohoto důvodu po roce 2002 výrazně zaměřovala na vzdělávací problémy neanglicky hovořících žáků (angl. English language learners; ELL). Hermanová a Abedi (2004) se snažili odhalit souvislost mezi demografickými a výkonovými daty u 602 žákủ v USA a tím, jak byly ve výuce pokryty různé tematické celky učiva matematiky. Ke sběru dat byl použit dotazník distribuovaný žákům a učitelům a přímé pozorování výuky. Z výsledků vyplynulo, že je možné identifikovat významné rozdíly ve výkonech jednotlivých žáků, ale také na úrovni školních tříd. Nedostatky stran pokrytí učiva byly identifikovány především ve tř́dách s převahou neanglicky hovo- 
řících žáků. Potvrdilo se, že př́ležitosti k učení (jejich operacionalizace byla částečně inspirována Stevensem - viz výše) jsou významným prediktorem školní úspěšnosti žáků. Martínez et al. (2010) zkoumali rozdíly ve výukových postupech u 53 učitelů působících v USA, kteří pracovali s anglicky plynně hovořícími žáky, a žáky, kteří angličtinu plně neovládali. Výzkumníci zjišt’ovali, jak pozorovaná výuka koresponduje s informacemi získanými z dotazníků a rozhovorů s učiteli. Výzkum ukázal, že výpovědi učitelů o dění ve třídě v dotaznících a rozhovorech se výrazně lišily od názoru výzkumníků. Výzkum dále ukázal, že neanglicky hovořící žáci mohou výrazně profitovat z toho, že učitelé používají odborný jazyk ve stejné míre jako u anglicky hovořících žáků. K obdobným výsledkům dospěli také Boscardin et al. (2004), Abedi et al. (2006) aj. Wangová (2010) v USA zkoumala, jak výukové postupy používané ve výuce matematiky souvisí s matematickými znalostmi a dovednostmi žáků a zda se odlišují výukové postupy v př́padě afroamerických žáků a žáků zasažených chudobou. Výzkumný vzorek tvořil reprezentativní soubor 23 tisíc žáků mateřských škol v USA. Ukázalo se, že afroamerickým žákům a žákům z nízkopř́íjmových rodin se dostává ve srovnání s běžnou populací méně kvalitních př́ležitostí k učení. Zejména kvůli tomu, že učitelé po těchto žácích nevyžadují složitější myšlenkové operace.

\subsection{Různorodost metod a technik pro zkoumání př́ležitostí k učení}

Koncept př́ležitostí $\mathrm{k}$ učení může být pojímán jako obecně didaktický i oborově didaktický koncept umožňující posuzovat a porovnávat procesy výuky v rámci různých vyučovacích předmětů. ${ }^{13}$ Výzkumné nástroje a související metody a techniky užívané ke zkoumání př́ležitostí k učení používané ve výzkumech představených $\mathrm{v}$ této podkapitole jsou poměrně různorodé. Jedná se především o:

- učitelské a žákovské dotazníky zjišttující napřs obsah výuky, dostupnost pomůcek a další kontextová a demografická data;

- obsahové analýzy kurikulárních dokumentů a dalších učitelských i žákovských materiálů za účelem získávání informací o plánovaných a realizovaných cílech a obsazích vzdělávání a jejich vnitřní a vnější koherence;

13 Jako inspirativní v tomto ohledu hodnotíme výzkumy př́ležitostí k učení ve výuce přírodních věd (Martínez et al., 2010) a matematiky (Burstein et al., 1995). 
- poznámky učitelů sloužící k zaznamenávání množství času věnovaného různým výukovým situacím a různým aktivitám žáků (vč. domácích úkolů apod.) a množství času, které přímo nesouvisí s odborným obsahem výuky;

- př́mé pozorování výuky, které může mimojiné vypověděto procentuálním podílu výukového času věnovaného určitému výukovému obsahu;

- videostudie umožňující analýzy výukových procesů, výukové komunikace a historicko-srovnávací analýzy;

- rozhovory s učiteli poskytující hlubší vhled do dění ve školních třídách.

Většina výzkumů příležitostí $\mathrm{k}$ učení současně využívá více uvedených metod a technik, proto je poměrně obtížné ke každé z nich exemplárně přiřadit konkrétní výzkumy. To na jednu stranu potvrzuje, že kombinací výzkumných metod a technik může být naplněna úloha empirického výzkumu vzdělávání, která spočívá ve zprostředkování empiricky podloženého vědění např. o předpokladech, procesech a kontextech vzdělávání a o vztazích mezi nimi (srov. Prenzel, 2012, s. 479). Na druhou stranu je ovšem třeba upozornit, že při realizaci náročnějších výzkumných designů se neobejdeme bez multidimenzionálních teoretických konceptů a modelů, které jsou v celé své komplexnosti čím dál méně empiricky uchopitelné. Př́ležitosti k učení tak v současnosti dle některých autorů představují koncept, který umožňuje zastřešovat výzkum školního vzdělávání v celé jeho komplexnosti (srov. McDonnell, 1995, s. 305). Přes toto všeobjímající konstatování je nicméně možné pozorovat, že koncept príležitostí k učení v současnosti pokrývá především dvě klíčová témata pedagogického výzkumu: hodnocení pedagogických situací pozorovatelných ve školní výuce (důraz je kladen na mikrorovinu školského systému, tedy na dění ve školních třídách) a hodnocení spravedlivosti, kvality a efektivnosti vzdělávání (důraz je kladen na makrorovinu školského systému). V mnohých výzkumech tato témata/roviny prolínají, často jsou také vztahovány k dalším kontextovým proměnným.

\section{Závěr}

V tomto textu jsme se pokusili zprostředkovat hlubší porozumění konceptu příležitostí k učení, který představuje výchozí teoretický koncept mnoha domácích i zahraničních výzkumů. Zájem o zkoumání příležitostí k učení stoupl zejména $\mathrm{v} 80$. letech 20 . stol., kdy byl koncept příležitostí $\mathrm{k}$ učení implementován do dokumentů vzdělávací politiky za účelem zajištění rovného 
př́ístupu ke vzdělávání. Obsahové vymezení příležitostí k učení se postupně rozšiřovalo od úzkého pojetí - př́ležitosti k učení jako koherence požadavků kurikula nebo standardizovaného testování a obsahu školní výuky, až po široce chápané - příležitosti k učení jako kategorie zastřešující obsáhlý soubor školních i mimoškolních faktorů ovlivňujících školní úspěšnost žáků. Jednotlivé dimenze příležitostí k učení informují výzkumníky o tom, s jakými vzdělávacími obsahy se určití žáci ve výuce setkávají, jak a kým jim jsou tyto obsahy zprostředkovávány, a jakými znalostmi, dovednostmi a postoji tito žáci disponují. Tomu odpovídá i široké spektrum metod a technik používaných k jejich zkoumání.

Vrat'me se nyní k otázce, zda je možné př́ležitosti k učení považovat za potřebný teoretický konstrukt. Př́ležitosti $\mathrm{k}$ učení se $\mathrm{v}$ pedagogické teorii a vzdělávací politice etablovaly jako koncept umožňující analyzovat souvislosti mezi vstupy a výstupy vzdělávání zejména prostřednictvím zkoumání procesuální stránky výuky (vztah mezi vyučováním a učením). Př́ležitosti k učení tak reprezentují teoretickou kategorii využitelnou pro zkoumání výuky uvnitř třídy, případně organizaci výuky ve škole, která funguje jako jeden z elementů komplexnějších a náročnějších výzkumů. $V$ těchto výzkumech je kromě samotných př́ležitostí $\mathrm{k}$ učení klíčový sběr kontextuálních dat o žácích a jejich výkonech, o učitelích apod. Pokud se zaměříme na výzkumy zastřešované konceptem příležitostí $\mathrm{k}$ učení realizované $\mathrm{u}$ nás, zjistíme, že př́ležitosti k učení ve většině případů představují především teoretické východisko zastřešující mikroanalýzy výuky. ${ }^{14}$ Primárním cílem těchto mikroanalýz je deskripce a explanace edukační reality na základě pojednávání o dílčích didaktických fenoménech zkoumaných na základě analýzy výukových situací, př́padně analýzy vybraných tematických celků učiva. Není tedy vždy možné prohlásit, že se v prostředí české a slovenské pedagogiky $\mathrm{s}$ př́ležitostmi $\mathrm{k}$ učení pracuje $\mathrm{v}$ souladu s jejich vymezením a teoretickým rozpracováním obvyklým zejména v USA, odkud tento koncept pochází. Kontextová data v případě mikroanalýz výuky z nejrůznějších důvodů chybí, což znesnadňuje formulaci teorií (a hypotéz) širšího okruhu platnosti. Z tohoto důvodu se domníváme, že není vždy nutné mikroanalýzy výuky realizované na úrovni analýzy výukových situací teoreticky zastřešovat konceptem

14 Mikroanalytické výzkumy bývají označovány jako „nová generace“ výzkumů vyučování a učení (srov. Janík, 2012, s. 254), jež primárně neoperují v paradigmatu proces-produkt. Jejich cílem je především elaborovat didaktický potenciál určitých výukových postupů s ohledem na facilitaci učení žáků. 
př́ležitostí k učení. Příležitosti k učení jako teoretický koncept nejsou s to teoreticky podepř́ít tento typ (mikro) analýz, nebot' slouží jako teoretická kategorie podpírající výzkumy makroroviny a mezoroviny školského systému. Ani samotné mikroanalýzy výuky většinou nemají cíl, potenciál ani ambice zpětně ovlivňovat pojetí, rozsah i obsah př́ležitostí k učení jako teoretické kategorie, nebot' si vystačí s operacionalizacemi tradičních konceptů obecné nebo oborové didaktiky.

Přestože východiskem zkoumání příležitostí $\mathrm{k}$ učení jsou srovnávací studie SIMS/TIMSS, a Česká republika má dlouhou tradici v realizování těchto studií ${ }^{15}$, není možné konstatovat, že by způsob zkoumání př́iležitostí k učení $\mathrm{v}$ těchto výzkumech inspiroval české výzkumníky $\mathrm{k}$ obdobně koncipované operacionalizaci př́ležitostí $\mathrm{k}$ učení. ${ }^{16}$ Koncept př́ležitostí $\mathrm{k}$ učení tak u nás často představuje spíše než teoretické a metodologické východisko pouze zajímavý název pro obsahově různorodé výzkumy realizované výzkumníky více či méně akcentujícími pedagogický konstruktivismus.

Závěrem nutno podotknout, že v zahraničí je aktuálně možné pozorovat postupné opouštění zájmu o zkoumání př́ležitostí k učení. Důvodem je zřejmě př́lišná komplexnost příležitostí $\mathrm{k}$ učení jako teoretického konceptu, v důsledku čehož se tento koncept stává čím dál méně empiricky uchopitelným. Potenciál př́ležitostí k učení jako teoretického konceptu se tak pravděpodobně již vyčerpal a zřejmě nastane období jejich rekonceptualizace inspirované v počáteční etapě jejich existence. Pro českou pedagogickou vědu by období rekonceptualizace příležitostí $\mathrm{k}$ učení mohlo být přínosné. V pozdní fázi kurikulární reformy, kdy přibývají doklady, že o kurikulární reformě možná ani není na místě hovořit, nebot’ nebyla implementována (srov. Dvořák, 2012; Janík, 2013 aj.), se začíná zejména diskutovat o tom, o co by v kurikulární reformě mělo jít především - o kvalitě kurikula a výuky. Jednotlivé dimenze př́ležitostí k učení (pokrytí obsahu, expozice obsahu, důležitost obsahu, kvalita vyučovacích postupů) a jejich operacionalizace, o nichž jsme pojednali v této studii, mohou pro současné i budoucí výzkumy kvality kurikula a výuky představovat cennou inspiraci.

15 Srov. studii Potužníkové, Lokajíčkové a Janíka (2014) v tomto čísle PedOr.

16 Důvody částečně odhalují Janík a Najvarová (2007), kteří upozorňují, že v ČR o mezinárodních výzkumech probíhá v odborné pedagogické komunitě pouze okrajová diskuse, jejich data nejsou až na výjimky využívána k sekundárním analýzám. Není tomu tak ale vždy. Videostudie TIMSS byla například jedním z inspiračních zdrojů videostudií realizovaných Institutem výzkumu školního vzdělávání PdF MU (podrobněji viz Janík \& Najvar, 2008). 


\section{Literatura}

Abedi, J., Courtney, M., Leon, S., Kao, J., \& Azzam, T. (2006). English language learners and math achievement: A study of opportunity to learn and language accommodation. Los Angeles: CRESST.

Boscardin, C. K., Aguirre-Muñoz, Z., Chinen, M., Leon, S., \& Shin, H. S. (2004). Consequences and validity of performance assessment for English learners: Assessing opportunity to learn (OTL) in grade 6 language arts. Los Angeles: CRESST.

Brewer, D. J., \& Stacz , C. (1996). Enhancing opportunity to learn measures in NCES data. Santa Monica: RAND.

Brophy, J. E., \& Good, T. L. (1986). Teacher behavior and student achievement. In M. Wittrock (Ed.), Handbook of research on teaching (s. 328-375). New York: Macmillan.

Burstein, L., McDonnell, L. M., Van Winkle, J., Ormseth, T. H., Mirocha, J., \& Guiton, G. (1995). Validating national curriculum indicators. Santa Monica, CA: Rand.

Carroll, J. (1963). A model of school learning. The Teachers College Record, 64(8), 723-733.

Coleman, J. S. (1968). Equality of educational opportunity. Integrated Education, 6(5), 19-28.

Cooley, W. W., \& Leinhardt, G. (1980). The instructional dimensions study. Educational Evaluation and Policy Analysis, 2(1), 7-25.

Crabbe, D. (2007). Learning opportunities: Adding learning value to tasks. ELT Journal, 61(2), 117-125.

Cueto, S., Ramirez, C., \& Leon, J. (2006). Opportunities to learn and achievement in mathematics in a sample of sixth grade students in Lima, Peru. Educational Studies in Mathematics, 62(1), 25-55.

Darling-Hammond, L. (1992). Standards of practice for learner-centered schools. New York: NCREST.

Dougherty, K. J. (1996). Opportunity-to-learn standards: A sociological critique. Sociology of Education, 69(Special Issue), 40-65.

Dvořák, D. (2010). Velké seřad'ovací nádraží: struktura školy a socializace dětí. Orbis scholae, $4(3), 63-78$.

Dvořák, D. (2011). Kurikulum 1. a 2. stupně: pohled na gramotnosti. In E. Walterová (Ed.), Dva světy základní školy? Úskalí přechodu z 1. na 2. stupeň (s. 82-102). Praha: Karolinum.

Dvořák, D. (2012). Nový institucionalismus v pedagogice. Studia paedagogica, 17(2), 9-26.

Gamoran, A. (2007). School accountability, American style: Dilemmas of high-stakes testing. Schweizerische Zeitschrift für Bildungswissenschaften, 29(1), 79-94.

Gamoran, A., Porter, A. C., Smithson, J., \& White, P. A. (1997). Upgrading high school mathematics instruction: Improving learning opportunities for low-achieving, low-income youth. Educational Evaluation and Policy Analysis, 19(4), 325-338.

Gardner, D. P., Larsen, Y. W., \& Baker, W. (1983). A nation at risk: The imperative for educational reform. Washington, DC: US Government Printing Office.

Greger, D. (2006). Kvalita a spravedlivost ve vzdělávání. In D. Greger \& V. Ježková (Eds.), Školní vzdělávání. Zahraniční trendy a inspirace (s. 52-68). Praha: Karolinum.

Greger, D. (2010). Nerovnosti ve vzdělávání - od konceptů k měření. In P. Matějů, J. Straková, \& A. Veselý (Eds.), Nerovnosti ve vzdělávání. Od měření k řešení (s. 22-37). Praha: SLON.

Gross, S. (1993). Early mathematics performance and achievement: Results of a study within a large suburban school system. The Journal of Negro Education, 62(3), 269-287. 
Guiton, G., \& Oakes, J. (1995). Opportunity to learn and conceptions of educational equality. Educational Evaluation and Policy Analysis, 17(3), 323-336.

Helmke, A. (2007). Unterrichtsqualität erfassen, bewerten, verbessern. Seelze: Kallmeyersche Verlagsbuchhandlung.

Herman, J. L., \& Abedi, J. (2004). Issues in assessing English language learners' opportunity to learn mathematics. Los Angeles: National Center for Research on Evaluation, Standards, and Student Testing (CRESST).

Herman, J. L., \& Klein, D. C. (1997). Assessing opportunity to learn: A California example. Los Angeles: CRESST.

Chvál, M., \& Kasíková, H. (2011). Př́ležitosti k rozvíjení kompetence k učení ve výuce: srovnání základních škol a víceletých gymnázií. Pedagogika, 61(2), 144-162.

Chvál, M., Kasíková, H., \& Valenta, J. (2012). Posuzování rozvoje kompetence k učení ve výuce. Praha: Karolinum.

Janík, T. (2012). Kvalita výuky: Vymezení pojmu a způsobů jeho užívání. Pedagogika, 62(3), 244-261.

Janík, T. (2013). Od reformy kurikula k produktivní kultuře vyučování a učení. Pedagogická orientace, 23(5), 634-663.

Janík, T., \& Najvar, P. (2008). Videostudie ve výzkumu vyučování a učení. Orbis scholae, 2(1), $7-28$.

Janík, T., \& Najvarová, V. (2007). Problémy školního vzdělávání ve světle výzkumů TIMSS a PISA (porovnání situace v České republice a v Německu). In D. Greger \& V. Ježková (Eds.), Školní vzdělávání: Zahraniční trendy a inspirace (102-123). Praha: Karolinum.

Janík, T., Lokajíčková, V., \& Janko, T. (2012). Komponenty a charakteristiky zakládající kvalitu výuky: přehled výzkumných zjištění. Orbis scholae, 6(1), 27-55.

Janík, T., Slavík, J., Mužík, V., Trna, J., Janko, T., Lokajíčková, V., ... \& Zlatníček, P. (2013). Kvalita (ve) vzdělávání: obsahově zaměřený př́stup ke zkoumání a zlepšování výuky. Brno: Masarykova univerzita.

Janíková, M. (2011). Interakce a komunikace učitelů tělesné výchovy. Brno: Paido.

Knecht, P., Janík, T., Najvar, P., Najvarová, V., \& Vlčková, K. (2010). Příležitost k rozvíjení kompetence k řešení problémů ve výuce na základních školách. Orbis scholae, 4(3), 37-62.

Leinhardt, G., \& Seewald, A. (1981). Overlap: What's tested, what's taught? Journal of Educational Measurement, 18(2), 85-96.

Lokajíčková, V. (2013). Kompetence k učení a možnosti jejího rozvíjení a hodnocení: vymezení pojmu a přehled současných přístupů. Pedagogická orientace, 23(3), 318-341.

Loveless, T. (2006). The peculiar politics of no child left behind. In A. Gamoran (Ed.), Standardsbased reform and the poverty gap: Lessons for «No Child Left Behind.» (s. 253-285). Washington, DC: Brookings Institution Press.

Mareš, J. (2013). Přehledové studie: jejich typologie, funkce a způsob vytváření. Pedagogická orientace, 23(4), 427-454.

Martínez, J. F., Bailey, A. L., Kerr, D., Huang, B. H., \& Beauregard, S. (2010). Measuring opportunity to learn and academic language exposure for English language learners in elementary science classrooms. Los Angeles: National Center for Research on Evaluation, Standards, and Student Testing (CRESST).

McDonnell, L. M. (1995). Opportunity to learn as a research concept and a policy instrument. Educational Evaluation and Policy Analysis, 17(3), 305-322. 
McDonnell, L. M., Burstein, L., Catteral, J., Ormseth, T., \& Moody, D. (1990). Discovering what schools really teach: Designing improved coursework indicators. Santa Monica: The Rand Corporation.

McPartland, J. M., \& Schneider, B. (1996). Opportunities to learn and student diversity: Prospects and pitfalls of a common core curriculum. Sociology of Education, 69(Extra Issue), 66-81.

Mudrák,J., \&Zábrodská, K. (2013). Lidský potenciál jako psychologický konstrukt. Československá psychologie, 57(3), 201-217.

Muthén, Huang, L. C., Jo, B., Khoo, S. T., Goff, G. N., Novak, J. R., \& Shih, J. C. (1995). Opportunityto-learn effects on achievement: Analytical aspects. Educational Evaluation and Policy Analysis, 17(3), 371-403.

Najvar, P., Najvarová, V., \& Janík, T. (2009). Lesson structure in different school subjects in the Czech Republic. Orbis scholae, 3(2), 113-127.

Najvar, P., Najvarová, V., Janík, T., \& Šebestová, S. (2011). Videostudie v pedagogickém výzkumu. Brno: Paido.

No child left behind act (2002). Washington: US Department of Education.

Oakes, J. (1992). Can tracking research inform practice? Technical, normative, and political considerations. Educational Researcher, 21(4), 12-21.

Porter, A. (1995). The uses and misuses of opportunity-to-learn standards. Educational Researcher, 24(1), 21-27.

Potužníková, E., Lokajíčková, V., \& Janík, T. (2014). Mezinárodní srovnávací výzkumy školního vzdělávání v České republice: zjištění a výzvy. Pedagogická orientace, 24(2), 185-221.

Prenzel, M. (2012). Empirický výzkum vzdělávání: vystačí naše stávající prrístupy zítra? Pedagogická orientace, 22(4), 475-489.

Raising standards for American education. A report to Congress, the Secretary of Education, the National Education Goals Panel, and the American people (1992). Washington: GPO.

Seidel, T., Prenzel, M., Rimmele, R., Dalehefte, I. M., Herweg, C., Kobarg, M., \& Schwindt, K. (2006). Blicke auf den Physikunterricht. Ergebnisse der IPN Videostudie. Zeitschrift für Pädagogik, 52(6), 799-821.

Shavelson, R. J., McDonnell, L. M., \& Oakes, J. (1989). Indicators for monitoring mathematics and science education. Santa Monica: Rand Corporation.

Schmidt, W. H., \& McKnight, C. C. (1995). Surveying educational opportunity in mathematics and science: An international perspective. Educational Evaluation and Policy Analysis, 17(3), 337-353.

Schneider, B., \& Coleman, J. S. (1993). Parents, their children, and schools. Boulder: Westview Press.

Slavík, J., \& Janík, T. (2012). Kvalita výuky: obsahově zaměřený přístup ke studiu procesů vyučování a učení. Pedagogika, 62(3), 262-287.

Stará, J. (2011). Výzkumy souladu záměru vzdělávacích programů s jejich implementací. Pedagogika, 61(3), 290-305.

Stevens, F. I. (1993). Applying an opportunity-to-learn conceptual framework to the investigation of the effects of teaching practices via secondary analyses of multiple-case-study summary data. The Journal of Negro Education, 62(3), 232-248.

Stevens, F. I., Wiltz, L., \& Bailey, M. (1998). Teachers' evaluations of the sustainability of opportunity to learn (OTL) assessment strategies. A national survey of classroom teachers in large urban school districts. Washington: Office of Educational Research and Improvement. 
Stevenson, D. L., Schiller, K. S., \& Schneider, B. (1994). Sequences of opportunities for learning. Sociology of Education, 67(3), 184-198.

Šebestová, S. (2011). Příležitosti $k$ rozvíjení rečových dovedností ve výuce anglického jazyka: videostudie. Brno: Masarykova univerzita.

Valverde, G. A., Bianchi, L. J., Wolfe, R. G., Schmidt, W. H., \& Houang, R. T. (2002). According to the book: Using TIMSS to investigate the translation of policy into practice through the world of textbooks. Dordrecht: Kluwer Academic Publishers.

Veselý, A., \& Matějů, P. (2010). Vzdělávací systémy a reprodukce vzdělanostních nerovností. In P. Matějů, J. Straková, \& A. Veselý (Eds.), Nerovnosti ve vzdělávání. Od měření k řešení (s. 38-90). Praha: SLON.

Wang, A. H. (2010). Optimizing early mathematics experiences for children from low-income families: A study on opportunity to learn mathematics. Early Childhood Education Journal, 37(4), 295-302.

Wang, J. (1998). Opportunity to learn: The impacts and policy implications. Educational Evaluation and Policy Analysis, 20(3), 137-156.

Welner, K. G., \& Oakes, J. (2008). Structuring curriculum: Technical, normative, and political considerations. In F. M. Connelly (Ed.), The Sage handbook of curriculum and instruction (s. 91-111). Thousand Oaks: SAGE.

Wiley, D. E., \& Yoon, B. (1995). Teacher reports on opportunity to learn: Analyses of the 1993 California Learning Assessment System (CLAS). Educational Evaluation and Policy Analysis, $17(3), 355-370$.

Zerzová, J. (2012). Interkulturní komunikační kompetence a její rozvíjení v hodinách anglického jazyka na 2. stupni Ž̌. Brno: Masarykova univerzita.

\section{Autor}

Mgr. Petr Knecht, Ph.D., Masarykova univerzita, Pedagogická fakulta, Institut výzkumu školního vzdělávání, Poříčí 7, 60300 Brno, e-mail: knecht@ped.muni.cz

\section{Opportunities to learn: Different/various conceptualisation and a review of research approaches}

Abstract: The aim of this review study is (a) to define the concept of opportunities to learn (OTL) as a theoretical category, (b) to present selected research tools that are most commonly used for investigating opportunities, and (c) to compare differences in defining and using opportunities to learn as a theoretical category in the Czech Republic and in the U.S., where the concept originated. In the first part of the study, a specific historical development of defining opportunities to learn is presented. Initially, the opportunities to learn were viewed as a theoretical category comprising the coherence between content of teaching and content requirements of (standardized) tests or curricula. Later, the scope of opportunities to learn 
expanded towards examining school-dependent variables and school-independent variables related to school performance of students. In the second part of the study opportunities to learn are operationalised, including examples of methods and techniques used for their investigation. On an example of selected research, the study shows that the concept of opportunities to learn in the U.S. primarily covers complex research-based analyses of the relationship between teaching and learning. This contrasts with the use of opportunities to learn as a theoretical concept in the Czech Republic, where opportunities to learn mainly represent a theoretical basis for conducting microanalyses of teaching.

Keywords: opportunity to learn, opportunities to learn, OTL, learning opportunity, educational opportunity, curriculum, instruction

Medková, I. (2013). Dovednosti žáků ve výuce fyziky na základní škole. Brno: Masarykova univerzita.

Publikace se zabývá problematikou osvojování fyzikálních dovedností žáků základní školy. Teoretická část je zaměřena především na různá chápání pojmu dovednost, klasifikaci dovedností a etapy procesu osvojování dovedností. Těžiště publikace spočívá v prezentaci tří výzkumných studií, které zjišt’ují úroveň osvojení dovedností žáky (pomocí didaktického testu), informovanost učitelů o dovednostech (pomocí dotazníků a rozhovorů) a postavení učebních úloh procesu osvojování dovedností (pomocí videostudie).

Tupý, J. (2014). Tvorba kurikulárních dokumentů v České republice. Brno: Masarykova univerzita.

Publikace mapuje tvorbu kurikulárních dokumentů a standardů pro základní vzdělávání od roku 1989 do první poloviny roku 2013. Charakterizuje základní koncepční dokumenty a změny ve školské legislativě, které ovlivňovaly vznik kurikulárních dokumentů od Učebních osnov pro základní vzdělávání z roku 1991, přes vzdělávací programy z poloviny 90. let minulého století až po Rámcový vzdělávací program pro základní vzdělávání (2005) i jeho první úpravy. Autor se snaží popsat a zhodnotit vše podstatné, co se při tvorbě kurikulárních dokumentů a standardů dařilo, případně nedařilo. $\mathrm{K}$ tomu využívá myšlenky a ukázky $\mathrm{z}$ koncepčních a legislativních dokumentů, z oficiálních materiálů MŠMT a dalších institucí, z interních textů kurikulárních ústavů, ze samotných kurikulárních dokumentů i z autentických dobových článků a rozhovorů. Každá etapa vývoje je v textu zhodnocena se snahou postihnout pozitivní a negativní kroky při tvorbě kurikulárních dokumentů, jejich schvalování a realizaci v praxi. 